\title{
Does A Strong Ethical Commitment Create A Strategic Human Resource Competitive Advantage?
}

Peter A. Stanwick, (E-mail: stanwpa@auburn.edu), Auburn University Sarah D. Stanwick, (E-mail: stanwsd@auburn.edu), Auburn University

\begin{abstract}
This paper empirically examined whether a comprehensive corporate ethical commitment by firms can create and enhance their competitive advantage by attracting and retaining the highest caliber of employees. The study examined the ethical commitment of the most desirable companies to work for in the United Kingdom by using a sample from The Times ranking of The 100 Best Firms to Work For In the UK. The results of the study showed that a majority of the firms that were desirable to work for also had a code of ethics, a commitment to corporate social responsibility, a commitment to serve the needs of their stakeholders, a commitment to be environmentally proactive and a commitment to establish a positive work environment for their employees
\end{abstract}

\section{INTRODUCTION}

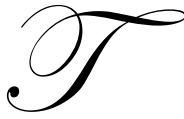

he purpose of this paper is to examine whether the firm's strong ethical commitment can have a positive impact on the selection and retention of the employees of a firm. The underlying argument of the paper is that if a firm is able to foster a strong positive ethical climate, that positive work experience can be converted into attracting and keeping the more qualified employees in that firm's industry. This paper extends the work of Barney (1986) who argued that a firm's culture can generate a competitive advantage. It is argued in this paper that the firm's ethical commitment within the firm's culture can aid in the firm's ability to differentiate its strategy by attaching the most qualified and most creative employees in the workforce. As a result, a strong ethical commitment can enhance the firm's relative competitive advantage (Wood 2002).

\section{THE ROLE OF ETHICS CORPORATE VALUES AS A COMPETITIVE ADVANTAGE}

Stevens, Steensma, Harrison and Cochran (2005) empirically examined the relationship between having a corporate code of ethics and the decision making process of the managers. Steven et al. (2005) found that managers would be more likely to integrated positive ethical actions if they felt it would help support the firm's internal culture as well as help give a strong positive image of the firm. It is through this transformational ability of managers that ethics can be incorporated into the everyday decision making process of the decision makers (Carlson and Perrewe, 1995). Carlson and Perrewe (1995) argue that the leadership style of the managers can help in the facilitation of institutionalizing corporate ethics beliefs into the firm's corporate culture.

However, the value system that is entrenched by the code of ethics of the firms is just one piece in the overall ethical values puzzle of the firm. For the ethical message and actions to be consistent within the firm, the firm must not only have a code of ethics but implement the same value systems as it relates to other interrelated relationships. 


\section{THE ROLE OF STAKEHOLDERS}

Firms do not operate within an internal vacuum. They must understand and respect the needs of various stakeholders. Stakeholders are defined as any interest group that has a vested interest in the operations of the firms. Some examples of stakeholders are: employees, suppliers, the government, local communities and society at large. Stakeholder theory is based on the ideal that firm's need to identify and manage the needs of the stakeholders in the decision making process (Hill and Jones, 1992; Mitchell, Agle and Wood, 1997; Quinn and Jones, 1995). It is through the management of these needs that firms are able to receive and maintain the support of these critical interest groups.

Stevens et al. (2005) found that managers would be more likely to integrate the ethical beliefs of the company from their code of ethics if they felt pressure from the firm's stakeholders.

\section{THE ROLE OF CORPORATE SOCIAL RESPONSIBILITY}

Corporate Social Responsibility integrates the different social responsibilities the firm has with its stakeholders. It is through an assessment of the firm's environmental, stakeholder and other related issues that the firm is able to identify what the desired outcomes should be. Wood (1991) proposes that social impacts, programs and policies should be the net result of any assessment of corporate social responsibility. As a result, it is expected that included in the firm's overall ethical value system, the firms would have a positive corporate social responsibility commitment to ensure that it meets the stakeholders' expectations. One of the social programs that would be considered part of the firm's corporate social responsibility is their commitment to corporate philanthropy. Porter and Kramer (2002) state the corporate philanthropy could be used to enhance a firm's competitive advantage. Porter and Kramer (2002) also warn that philanthropy should not be used as solely a way to enhance the firm's corporate reputation but should be used strategically. An example of strategic corporate philanthropy would be a firm supporting education programs in the local community which would subsequently enhance the skill base of the potential employees for the firm.

\section{THE ROLE OF THE NATURAL ENVIRONMENT}

It is also expected that firms with a high commitment to strong ethical values would also perceive the natural environment as a potential stakeholder. Firms that have a strong commitment to the natural environment can use it to develop a competitive advantage (Porter and Van der Linde, 1995) and potentially higher levels of profitability (Stanwick and Stanwick 1998). As a result, the natural environment would be considered another opportunity in which the firm is able to display its ethical value system to current stakeholders as well as potential new stakeholders such as employee candidates.

As was stated previously, the impact that ethical values of the firm can be viewed from a corporate social responsibility perspective. Wood (1991) states that corporate social performance and corporate social responsibility is the umbrella approach to understand how the value system of the firm can help guide the behavior of the employees of the firm. The firm has an ethical commitment to not only the stockholders of the company but also to any interested stakeholders. It is within these broader guidelines that ethical commitment through a code of ethics could be considered just one part of the overall value system. In addition, to understand the value system of the firm, not only is it necessary to examine whether the firm has a code of ethics, but it is also necessary to examine the firm's commitment to corporate social responsibility and various stakeholders with special interest to the commitment of the employees. Furthermore, it is expected the firms with a positive value system would also have a strong commitment to decisions that achieve objectives pertaining to the natural environment.

Therefore the Hypotheses to be empirically examined in this paper are:

H1: A majority of the firms in the sample will have a code of ethics.

H2: A majority of the firms in the sample will have a description of the firm's corporate social responsibility commitment. 
H3: A majority of the firms in the sample will have a description of their commitment to satisfying the needs of various stakeholders.

H4: A majority of the firms in the sample will have a description of the commitment to their employees.

H5: A majority of the firms in the sample will have a description to their commitment to the natural environment.

\section{METHODOLOGY}

\section{Sample}

The sample was selected from the firms listed The Times ranking of The 100 Best Firms to Work For In the UK. The listing is based on ranking firms that do business in the United Kingdom on six criteria. The criteria are: leadership, wellbeing, belonging, giving back to the community and personal growth. Of the 100 firms listed in the rankings, 40 firms were randomly selected for the sample. For each firm in the sample, a content analysis was done on the information that was available from the firm's web site. The firms in the sample are shown in Table 1.

\section{Results}

A content analysis of the information pertaining to the ethical value system of the firms yielded interesting results. Of the 40 firms in the sample, 33 firms had a code of ethics listed on the web site. As a result, Hypothesis 1 is supported. A majority of the firms ( 82.5 percent) of the firms did have a code of ethics to help foster a positive ethical climate within the firm.

The results also showed that 29 of the 40 firms described their commitment to corporate social responsibility. As a result, Hypothesis 2 is supported since 72.5 percent of the firms described their corporate social commitment. Hypothesis 3 was also supported since 33 firms ( 82.5 percent) described their commitment to serving the needs of the firm's stakeholders. A description of the firm's commitment to their employees yielded the highest percentage in the sample of 95 percent. Thirty eight of the forty firms described how they tried to ensure a positive work environmental through their commitment to their employees which supported Hypothesis 4. Hypothesis 5 was also supported since a majority of the firms, 24 firms or 60 percent of the sample described their commitment to the natural environment on their web site.

\section{DISCUSSION}

The results of the study have supported the underlying premise which was that highly desirable firms to work for also have a strong positive ethical value system. By supporting each of the five Hypotheses presented in the study, the results showed that firms are aware of the potential benefits of being ethically "proactive". Since this information is publicly available on their web sites, potential employee candidates would be able to review their ethical value system before they apply for a job.

In addition, the firms realize that the recruitment of the employees is only the first step in having a highly qualified workforce. In order to retain the most qualified employees, the firms must foster an ethically supportive culture. It is not surprising that ninety five percent of the firms in the study had a description on how they are committed in making the work environment beneficial to the employees.

An interesting result from the study is the type of industries represented on the list. Thirty five or 87.5 percent of the firms in the study are from service industries. On the thirty service based firms, 10 of those firms are consulting firms. This result can also support the premise that firms need to have an ethical "friendly" environment for their employees. Since consultants have a skill base to be able to move freely from one company to another, it appears that the consulting firms are doing whatever they can in order to attach and retain the top consultants in their respective fields. 
Table 1

Firms In the Study

Firm
Avis
ARUP
Admiral Group
Bettys \& Taylors
Boehringer Ingelheim
Bacardi-Martini
Badenock and Clark
BDO Stoy Hayward
Birse
Bramall Construction
BUPA
Camelot
Central Office of Information
Coloplast
Data Connection
Drivers Jonas
Flight Centre
Faber Maunsell
Gerald Eve
Holroyd Howe
Honda
Heat
Hiscox
Lush
Martineau Johnson
Macquarie Bank
Penna
Pinnacle
Peter Brett
Plus
Robert Half
Sapient
Style and Wood
Sthree
ScS
Southdown Housing
St. Ann's Hospice
Towers and Hamlins
Wragge
Yorkshire Forward

Industry

Car Rental

Engineering Consultants

Insurance

Food Manufacturer

Drug Manufacturer

Drink Manufacturer

Recruitment Consultants

Business Consultants

Civil Engineering

Construction

Health Insurance

Lottery

Government Agency

Medical Devices Supplier

Computer Software

Property Consultants

Travel Agency

Consultants

Property Consultants

Contract Caterer

Transportation Equipment Sales

Housing Specialist

Insurer

Cosmetics Manufacturer

Law Firm

Financial Services

Professional Consultants

Professional Consultants

Engineering Consultants

Housing Association

Recruitment Consultants

Professional Consultants

Business Services

Professional Recruiting

Retailer

Housing Association

Hospice

Law Firm

Law Firm

Regional Development Agency 


\section{REFERENCES}

1. Barney J. 1986. Organizational culture: Can it be a Source of Sustained Competitive Advantage? Academy of Management Review. 11(3): 656-665.

2. Carlson, D., \& Perrewe, P. 1995. Institutionalization of Organizational Ethics Through Transformational Leadership. Journal of Business Ethics. 14(10): 829-838.

3. Hill, C., \& Jones, T. 1992. Stakeholder-Agency Theory. Journal of Management Studies. 29: 131-154.

4. Mitchell, R., Agle B., Wood D. 1997. Toward a Theory of Stakeholder Identification and Salience: Defining the Principle of Who and What Really Counts. Academy of Management Review. 22(4): 853-886.

5. Porter, M., \& Van Der Linde, C. 1995. Green and Competitive: Ending the Stalemate. Harvard Business Review. 73(5): 120-134.

6. Porter, M. \& Kramer, M. 2002. The Competitive Advantage of Corporate Philanthropy. Harvard Business Review. 80(12): 56-68.

7. Quinn, D., \& Jones, T. 1995. An Agent Morality View of Business Policy. Academy of Management Review. 20:22-42.

8. Stanwick, P., \& Stanwick, S. 1998. The Relationship Between Corporate Social Performance, and Organizational Size, Financial Performance, and Environmental Performance: An Empirical Examination. Journal of Business Ethics. 17(2): 195-204.

9. Stevens, J., Steensma, H., Harrison, D. and P. Cochran. 2005. Symbolic or Substantive Document? The Influence of Ethics Codes on Financial Executives' Decisions. Strategic Management Journal. 26: 181-195.

10. Wood, D. Corporate Social Performance Revisited. 1991. Academy of Management Review. 16(4): 691-718.

11. Wood, G. 2002. A Partnership Model of Corporate Ethics. Journal of Business Ethics. 40(1): 61-73.

\section{NOTES}




\section{NOTES}

